\title{
Pengaruh Strategi Scaffolding dalam Penyajian Contoh Problem Solving terhadap Hasil Belajar Fisika Siswa Kelas VIII SMP Negeri 1 Sindue Tombusabora
}

\author{
Moh Asri, Muslimin, dan Jusman Mansyur \\ mohasri955@gmail.com \\ Program Studi Pendidikan Fisika FKIP Universitas Tadulako \\ Jl. Soekarno Hatta Km. 9 Kampus Bumi Tadulako Tondo Palu - Sulawesi Tengah
}

\begin{abstract}
Abstrak -Tujuan penelitian ini adalah untuk mengetahui ada tidaknya pengaruh strategi scaffolding dalam penyajian contoh problem solving terhadap hasil belajar fisika siswa kelas VIII SMP Negeri 1 Sindue Tombusabora. Hipotesis yang diajukan dalam penelitian ini yaitu terdapat pengaruh strategi scaffolding dalam penyajian contoh problem solving terhadap hasil belajar fisika siswa kelas VIII SMP Negeri 1 Sindue Tombusabora. Populasi penelitian ini adalah seluruh siswa kelas VIII SMP Negeri 1 Sindue Tombusabora. Pengambilan sampel dilakukan secara purposive sampling. Berdasarkan uji hipotesis diperoleh $t_{\text {hitung }}>t_{\text {tabel }}=$ $2,44>2,01$ dengan taraf signifikasi $\alpha=0,05$. Maka $\mathrm{H}_{0}$ ditolak dan $\mathrm{H}_{1}$ diterima. Hasilya dapat disimpulkan bahwa terdapat perbedaan hasil belajar fisika antara kelas yang mengikuti strategi scaffolding dalam penyajian contoh problem solving dengan siswa yang mengikuti model pembelajaran konvensional. Siswa yang mengikuti pembelajaran dengan strategi scaffolding dalam penyajian contoh problem solving lebih terbantu dalam memecahkan masalah dengan menggunakan tahapan Polya dibandingkan dengan siswa yang mengikuti pembelajaran konvensional.
\end{abstract}

Kata Kunci: strategi scaffolding, Problem Solving, Hasil Belajar Fisika.

\section{PENDAHULUAN}

Scaffolding merupakan pemberian intervensi atau bantuan oleh guru diberikan pada saat siswa sudah merasa sangat kesulitan, yakni ketika ia benar-benar berada di ujung kemampuan aktualnya. Dengan diberikan bantuan misalnya dengan contoh, diskusi, petunjuk, pertanyaan, siswa dapat menuju kemampuan potensialnya, dan jika siswa telah sampai pada tingkat yang lebih sulit lagi, bantuan pun dapat kembali diberikan begitu seterusnya. Sehingga siswa tidak akan merasa terganggu dan merasa diabaikan. Scaffolding merupakan jembatan yang digunakan untuk menghubungakan apa yang sudah diketahui oleh siswa dengan konsep baru[1].

Menyelesaikan masalah (problem solving) dalam fisika diperlukan langkah-langkah yang sistematis agar proses penyelesaiannya mudah dan terarah. Problem solving merupakan suatu cara belajar yang dianggap efisien dalam usaha untuk mencapai tujuan pengajaran. Problem solving adalah suatu cara yang dilakukan seseorang dengan menggunakan pengetahuan, keterampilan dan pemahaman untuk memenuhi tuntutan dari situasi yang tidak rutin ${ }^{[2]}$.

Problem solving didefinisikan sebagai usaha untuk mencari jalan keluar dari suatu kesulitan untuk mencapai tujuan tidak dapat segera dicapai. Secara sederhana, pemecahan teoritis merupakan proses penerimaan sebagai masalah sebagai tantangan untuk menyelesaikan masalah tersebut ${ }^{[3]}$.

Problem solving adalah elemen penting dari belajar fisika. Namun, instruksi tradisional sering menekankan aspek kuantitatif pemecahan masalah seperti persamaan dan prosedur matematika bukan analisis kualitatif untuk memilih konsep dan prinsip-prinsip yang sesuai. Instruksional dalam pemecahan masalah konseptual membimbing siswa untuk mengidentifikasi prinsip-prinsip, membenarkan, dan rencana solusi mereka secara tertulis sebelum memecahkan masalah[4].

Memecahkan masalah (problem solving), ahli pertama mencari konsep yang mendasari, sementara siswa cenderung untuk mencari persamaan dan contoh sebelumnya untuk bekerja. Sebelum memecahkan masalah, siswa dingatkan untuk mencari konsep yang mendasari masalah tersebut yang dibantu dengan scaffolding untuk mengarahkan perhatian siswa terhadap konsep-konsep yang mendasari. Hasil menunjukkan bahwa scaffolding mendorong siswa untuk mencari dan menerapkan prinsip-prinsip dasar yang tepat dalam memecahkan masalah ${ }^{[5]}$. Scaffolding adalah perlakuan intervensi yang diberikan kepada siswa atau kelompok belajar siswa secara bertahap dalam memecahkan masalah ${ }^{[6]}$.

Berdasarkan uraian di atas menunjukkan bahwa pemecahan masalah fisika oleh siswa tidak 
terlepas dari dukungan oleh seorang guru kepada siswa dalam memcahkan masalah. Peneliti menganggap penting untuk dilakukan penelitian tentang pengaruh strategi scaffolding dalalm penyajian contoh problem solving terhadap hasil belajar fisika siswa, yaitu menggabungkan antara strategi scaffolding dengan problem solving terhadap hasil belajar fisika siswa.

\section{METODE PENELITIAN}

Penelitian yang digunakan adalah jenis penelitian dengan rancangan eksperimen kuasi (equasi-experimental design). Desain penelitian yang digunakan yaitu Nonequivalent Control group design. Desain penelitian yang digunakan dapat dilukiskan seperti pada Tabel 1.

TABEL 1 DESAIN PENELITIAN

\begin{tabular}{cccc}
\hline Kelompok & Pra tes & Perlakuan & Pascates \\
\hline Eksperimen & $\mathrm{O}$ & $\mathrm{X}$ & $\mathrm{O}$ \\
Kontrol & $\mathrm{O}$ & - & $\mathrm{O}$ \\
\hline
\end{tabular}

Penelitian dilakukan di SMP Negeri 1 Sindue Tombusabora. Populasi dalam penelitian ini adalah seluruh siswa kelas VIII SMP Negeri 1 Sindue Tombusabora, tahun pelajaran 2016/2017 semester genap yang terdiri dari 4 kelas. Sampel dalam penelitian ini adalah kelas VIII C yang berjumlah 24 siswa dan VIII D yang berjumlah 25 siswa. Teknik penentuan sampel yang digunakan adalah purposive sampling. Instrumen yang digunakan dalam penelitian ini adalah tes pilihan ganda untuk melihat hasil belajar siswa pada mata pelajaran fisika.

Instrumen penelitian ini proses validasi dilakukan oleh validator ahli. Dimana soal yang telah dibuat dikonsultasikan kepada validator ahli kemudian divalidasi dan direvisi. Validasi yang diuji adalah validasi ahli dan validasi konstruksi. Berdasarkan hasil validasi oleh validator ahli sebanyak 40 soal yang telah mewakili masing-masing indikator pencapaian hasil belajar, diperoleh 40 soal semua valid yang selanjutnya akan dilanjutkan pada tahap uji coba soal. Soal yang telah di validasi oleh ahli kemudian diujicobakan di kelas IXC SMP Negeri 1 Sindue Tombusabora. Dimana pemilihan kelas ini karena di kelas tersebut telah mempelajari materi pesawat sederhana. Uji coba dilakukan dengan tujuan untuk mengetahui validitas, reliabilitas, daya pembeda dan tingkat kesulitan dari instrument tersebut. Adapun instrumen yang diujikan terdiri atas 35 item soal. Uji coba dilakukan dengan tujuan untuk mengetahui validitas, reliabilitas, daya pembeda dan tingkat kesulitan dari instrumen tersebut. Hasil Uji coba yang telah di uji validitas, reliabilitas, daya pembeda dan tingkat kesulitannya diperoleh 26 instrumen yang layak digunakan.

Analisis data dilakukan dengan menganalisis instrumen terlebih dahulu menggunakan uji validitas item dan reliabilitas tes yang kemudian dengan menganalisis data hasil penelitian menggunakan asumsi normal dan homogen setelah itu uji hipotesis.

\section{HASIL DAN PEMBAHASAN}

\section{A. Hasil Penelitian}

Uji hipotesis digunakan untuk menguji apakah hipotesis dapat diterima atau tidak. Pengujian ini menggunakan uji-t dengan pasangan hipotesis sebagai berikut:

$\mathrm{H}_{0}: \mu_{0}=\mu_{1}$ : Tidak terdapat pengaruh hasil belajar fisika antara kelompok yang menggunakan strategi scaffolding dalam penyajian contoh problem solving dengan kelompok yang menggunakan model pembelajaran konvensional.

$\mathrm{H}_{1}: \mu_{0} \neq \mu_{1}$ : Terdapat pengaruh hasil belajar fisika antara kelompok yang menggunakan strategi scaffolding dalam penyajian contoh problem solving dengan kelompok yang menggunakan model pembelajaran konvensional.

TABEL 2 DESKRIPSI SKOR TES HASIL BELAJAR FISIKA UNTUK KELAS EKSPERIMEN DAN KELAS KONTROL.

\begin{tabular}{lcc}
\hline \multicolumn{1}{c}{ Uraian } & \multicolumn{2}{c}{ Posttest } \\
\cline { 2 - 3 } & Eksperimen & Kontrol \\
\hline Sampel $(\mathrm{n})$ & 24 & 25 \\
Nilai maksimum & 17 & 14 \\
Nilai minimum & 7 & 4 \\
Skor rata-rata & 12.04 & 9,56 \\
Standar deviasi & 3,06 & 2.81 \\
\hline
\end{tabular}

Berdasarkan nilai rata-rata posttest kelas eksperimen sebesar 12 dan kelas control sebesar 9,62, dilakukan uji hipotesis (uji-t) beda rata-rata (dua pihak) dan diketahui nilai $t_{\text {hitung }}=2,44$. Selanjutnya untuk nilai $t_{\text {tabel }}=\mathrm{t}_{(1-}$ $1 / 2 \mathrm{a})$ pada taraf nyata $\mathrm{a}=0,05$ dan $\mathrm{dk}=\left(\mathrm{n}_{1}+\right.$ $\left.\mathrm{n}_{2}\right)=24+25-2=47$, untuk harga t lainnya $\mathrm{H}_{0}$ ditolak. Dari daftar distribusi diperoleh tabel $=$ 2,01. Kriteria $\mathrm{H}_{0}$ diterima jika thitung $<\mathrm{t}_{\text {tabel }}$ dan $\mathrm{dk}=\left(\mathrm{n}_{1}+\mathrm{n}_{2}-2\right)=24+25-2=47$ pada taraf nyata $a=0,05$, untuk harga $t$ lainnya $\mathrm{H}_{0}$ ditolak. Dari daftar distribusi diperoleh tabel $=$ 2,01 sedangkan dari hasil perhitungan uji-t diperoleh nilai thitung $=2,44$ yang berada di luar daerah penerimaan $\mathrm{H}_{0}$. Hal ini berarti thitung $>$ 
tabel $=2,44>2,01$; dengan demikian $\mathrm{H}_{0}$ di tolak dalam taraf nyata $\mathrm{a}=0,05$ dan $\mathrm{H}_{1}$ diterima. Uji t tersebut diperoleh berdasarkan data tes akhir. hasil dapat dilihat pada Tabel 3.

TABEL 3 HASIL UJI BEDA RATA-RATA TES AKHIR KELAS EKSPERIMEN DAN KELAS KONTROL.

\begin{tabular}{ccccc}
\hline Kelas & $\begin{array}{c}\text { Nilai rata- } \\
\text { rata }(\bar{X})\end{array}$ & $\mathrm{t}$ hitung & $\mathrm{t}$ table & $\begin{array}{c}\text { Keputusa } \\
\mathrm{n}\end{array}$ \\
\hline $\begin{array}{c}\text { Kelas } \\
\text { Eksperimen }\end{array}$ & 12 & 2,44 & 2,01 & $\mathrm{H}_{0}$ ditolak \\
$\begin{array}{c}\text { Kelas } \\
\text { Kontrol }\end{array}$ & 9,62 & & & \\
\hline
\end{tabular}

Tabel 3 menunjukan bahwa dengan demikian $\mathrm{H}_{0}$ ditolak dan $\mathrm{H}_{1}$ diterima, dan dapat disimpulkan bahwa ada terdapat perbedaan hasil belajar fisika antara kelompok yang menggunakan strategi scaffolding dalam penyajian contoh problem solving dengan kelompok yang menggunakan model pembelajaran konvensional. Artinya, bahwa strategi scaffolding dalam penyajian contoh problem solving mempengaruhi hasil belajar fisika.

\section{B. Pembahasan}

Analisis akhir dari posttest menunjukkan bahwa perolehan nilai rata-rata untuk kelas eksperimen adalah 12 dan untuk kelas kontrol diperoleh nilai rata-rata yaitu 9,62. Data postest berdistribusi normal dan memiliki varians yang homogen, kemudian dilakukan uji hipotesis (menggunakan uji dua pihak) dan didapatkan hasil bahwa terdapat perbedaan hasil belajar antara kelas eksperimen dan kelas kontrol.

Berdasarkan uji hipotesis yang telah dilakukan diperoleh nilai $x$ rata-rata untuk kelas eksperimen yaitu 12 , kelas kontrol 9,62 dan untuk $t_{\text {hitung }}=2,44$ dan $t_{\text {tabel }}=2,01$. karena nilai $t_{\text {hitung }}>t_{\text {tabel }}$, taraf signifikan $\alpha=0,05$ maka $\mathrm{H}_{0}$ ditolak atau $\mathrm{H}_{1}$ diterima. Sehingga dapat disimpulkan bahwa ada perbedaan hasil belajar fisika siswa yang menggunakan strategi scafolding dalam penyajian contoh problem solving dengan kelompok yang menggunakan model pembelajaran konvensional di SMP Negeri 1 sindue Tombusabora.

Strategi scaffolding dalam penyajian contoh problem solving adalah strategi pembelajaran yang diberikan kepada siswa oleh guru, dimana guru memberikan penjelasan materi yang diajarkan kepada siswa. Setelah itu guru memberikan kesempatan kepada siswa untuk bertanya tentang materi yang tidak dimengerti dan guru memberikan penjelasan dengan baik. Setelah siswa paham dengan materi yang diajarkan maka guru memberikan contoh soal materi yang diajarkan satu sampai tiga contoh.
Pemberian contoh oleh guru kepada siswa dengan pemecahannya menggunakan tahapan Polya. Scaffolding berperan sebagai bantuan atau menjembatani siswa ketika mengalami kesulitan dalam memecahkan masala. Contoh yang kedua yang diberikan siswa yang mengerjakannya didepan kelas dengan bantuan dikurangi dari sebelumnya begitupun contoh yang ketiga.

Setelah siswa paham dengan contoh yang diberikan, selanjutnya guru memberikan latihan kepada siswa yang terdiri dari latihan satu, dua dan tiga. Latihan yang diberikan kepada siswa tidak lepas dari bantuan scaffolding. Bantuan scaffolding akan diberikan ketika siswa mengalami kesulitan, dimana siswa mengalami kesulitan atau sampai pada kemampuan aktualnya.

Terjadinya perbedaan hasil belajar terutama pada kelas eksperimen, karena pada proses pembelajaran menggunakan strategi scaffolding dalam penyajian contoh problem solving, siswa lebih aktif dalam memecahkan masalah dan terlibat langsung dalam proses pembelajaran dimana informasi dan pengetahuan mereka temukan dari penjelasan guru dan berperan langsung dalam memecahkan masalah baik itu secara individu maupun berkelompok. Berkelompok siswa dapat berdiskusi sesama mereka dan bertukar informasi dalam memecahkan masalah menggunakan tahapan Polya. Sehinnga hasil belajar siswa secara individu maupun berkelompok meningkat.

Hasil belajar ini menunjukan bahwa hasil belajar fisika siswa yang mengikuti proses pembelajaran yang menggunakan strategi scaffolding dalam penyajian contoh problem solving lebih baik daripada yang mengikuti pembelajaran menggunakan model pembelajaran konvensional. Karena pada kelas kontrol ini keaktifan guru lebih dominan dibandingkan keaktifan siswa, sehingga siswa hanya mendengarkan dan menulis penjelasan yang diberikan oleh guru.

Pembelajaran konvensional (model pembelajaranan langsung) umumnya menggunakan metode ceramah, dalam hal ini guru berperan aktif dalam proses pembelajaran dan siswa hanya sebagai penyimak dan pendengar saja dalam menangkap ilmu yang disampaikan oleh guru. Proses pembelajaran berlangsung menoton dimana guru hanya menjelaskan, memberikan contoh soal dan memberikan latihan. Sehingga proses pembelajaran seperti ini akan menumbuhkan rasa jenuh dalam diri siswa sehingga berakibat tidak suka terhadap mata pelajaran yang tersebut ${ }^{[7]}$. 
Hasil yang diperoleh pada penelitian ini menunjukkan bahwa hasil belajar fisika siswa yang diajarkan strategi scaffolding dalam penyajian problem solving lebih tinggi dibandingkan dengan hasil belajar fisika siswa yang diajarkan dengan model pembelajaran konvensional. Hasil ini didukung oleh Penelitian sebelumnya yang menunjukan bahwa mahasiswa yang diajar dengan bantuan scaffolding lebih menerimah, banyak memberikan umpan balik dan sangat membantu mahasiswa dalam memahami fisika khusunya bagi pemula yang rendah berprestasi dalam belajar fisika ${ }^{[8]}$.

Hasil penelitian ini sejalan dengan peneliti sebelumnya yaitu meningkatkan kemampuan siswa pada materi hukum Gauss dengan rancangan strategi scaffolding. Hasil penelitiannya menunjukan bahwa bahwa strategi tersebut sangat mempengaruhi siswa secara positif dalam memahami hukum Gauss sehingga meningkatkan kinerja dalam menerjemahkan antara matematika dan grafis serta siswa yang menyadari bahwa medan listrik berperilaku berbeda di berbagai daerah dibandingkan siswa yang diajar dengan pembelajaran konvensional ${ }^{[9]}$.

Penelitian ini juga senada dengan peneliti tentang pengaruh intruksi problem solving eksplisit terhadap kinerja pemecahan masalah siswa SMA dan pemahaman konseptual fisika. Hasilnya menunjukkan bahwa intruksi problem solving eksplisit meningkatkan kualitas dan kelengkapan representasi fisika siswa dan intruksi problem solving eksplisit sangat bermanfaat bagi siswa khususnya dalam memecahkan masalah dengan baik dan tepat ${ }^{[10]}$.

Penelitian ini memiliki kesamaan dengan penelitian-penelitian di atas, akan tetapi penelitian ini menggabungkan antara strategi scaffolding dengan problem solving. Strategi scaffolding dengan pemecahan masalah diujicobakan secara bersama pada kelas ekperimen dengan menggunakan strategi scaffolding dalam penyajian contoh problem solving dan kelas kontrol dengan menggunakan pembelajaran konvensional. Hasil yang didapatkan pada tes akhir pada kelas ekperimen lebih tinggi dibandingkan pada tes akhir di kelas control, sehingga memiliki kesimpulan yang sama bahwa terdapat pengaruh strategi scaffolding dalam penyajian contoh dengan problem solving terhadap hasil belajar fisika siswa.

Proses belajar mengajar di kelas ekperimen dan kelas kontrol sebenarnya mempunyai tujuan pembelajaran yang sama yaitu membuat siswa lebih mengerti tentang bagaimana memecahkan masalah dengan baik dan mudah dengan tahapan Polya yang diberikan oleh guru. Kedua kelas tersebut memiliki hasil belajar lebih tinggi dari sebelumnya setelah diterapkan pembelajaran yang berbeda. Akan tetapi selain kesamaan, kedua kelas tersebut terdapat perbedaan yaitu di dalam problem solving akan menimbulkan keaktifan siswa, motivasi belajar, kerja sama dan meningkatkan kreativitas dalam belajar sehingga siswa mendapat kesempatan untuk menemukan dan menetapkan ide mereka sendiri. Sedangkan pada kelas kontrol siswa cenderung lebih pasif. Perbedaan tersebut menunjukkan adanya pengaruh model pembelajaran yang digunakan pada kelas eksperimen dan kelas eksperimen kontrol.

\section{KESIMPULAN DAN SARAN}

Berdasarkan hasil analisis data uji hipotesis yang dilakukan dengan teknik statistik uji-t dua pihak untuk menguji perbedaan rerata skor hasil belajar siswa dengan strategi scaffolding dalam penyajian contoh problem solving, hasilnya bepengaruh secara signifikan pada taraf nyata $\alpha=0,05$.

Berdasarkan hasil penelitian yang telah dilakukan, preneliti mengajukan beberapa saran sebagai berikut:

1. Diharapkan dalam proses pembelajaran fisika guru kiranya dapat mempertimbangkan strategi scaffolding dalam penyajian contoh problem solving sebagai salah satu alternatif dalam usaha untuk meningkatkan hasil belajar siswa pada umumnya hasil belajar fisika pada khususnya.

2. Kepada mahasiswa khususnya program stidi pendidikan fisika dapat mencoba menerapkan strategi scaffolding dalam penyajian contoh problem solving pada penelitian mereka dengan materi yang berbeda untuk mengetahui pengaruh strategi ini dalam pembelajaran fisika.

\section{DAFTAR PUSTAKA}

[1] Budiningsih, C.A. (2008). Belajar Dan Pembelajaran. Jakarta: Rineka Cipta

[2] Krulik, S dan Rudnick, J.A. (1995). The New Sourcebook for Teaching Reasoning and Problem Solving in Elementary School. Needham Heights: Allyn \& Bacon.

[3] Handayani, L. (2016). Konsistensi Siswa dalam Pemecahan Masalah Fisika untuk Urutan Pertanyaan Termodifikasi. Jurnal Pendidikan Fisika Tadulako (JPFT) Vol. 3 No. 3. ISSN 23383240.

[4] Docktor, J. L. (2015). Conceptual Problem Solving In High School Physics. Physical Review Special Topics Physics Education Research 11, 020106 (2015). 
[5] Ding, L. (2011). Exploring The Role Of Conceptual Scaffolding In Solving Synthesis Problems. Physical Review Special Topics - Physics Education Research 7, 020109 (2011).

[6] Lin, S-Y. (2015). Effect Of Scaffolding On Helping Introductory Physics Students Solve Quantitative Problems Involving Strong Alternative Conceptions. [Online]. Tersedia : physical review special topicsphysics education research 11, 020105 (2015).

[7] Mujiati (2012). Perbedaan Hasil Belajar Fisika Antara Penerapan Model Pembelajaran Kooperatif Tipe Artikulasi dengan Pembelajaran Konvensional pada Siswa Kelas VIII SMP Negeri 14 Palu. Skripsi Universitas Tadulako Palu : tidak diterbitkan.
[8] Lindstrom, C and Manjula D. Sharma. (2011). Teaching Physics Novices At University: A Case For Stronger Scaffolding. Physical Review Special Topics - Physics Education Research 7, 010109 (2011).

[9] Maries, A., Lin and Singh. (2017). Challenges in designing appropriate scaffolding to improve students'representational consistency: The case of a Gauss's law problem. [Online]. Tersedia : Hysical Review Physics Education Research 13, 020103 (2017).

[10] Huffman, D. (1997). Effect Of Explicit Problem Solving Instruction On High School Students' Problem-Solving Performance And Conceptual Understanding of Physics. J. Res. Sci. Teach.34, 551 (1997). 